\title{
MOROCCO E-READINESS ASSESSMENT: UNIVERSITY CONTRIBUTION
}

\author{
Abdelmajid Bouziane, Hassan II University of Casablanca, Morocco \\ Rachid Elaasri, Hassan II University of Casablanca, Morocco
}

\begin{abstract}
The main purpose of this study is to explore the critical issues that impede an effective implementation of information communication technology (ICT) as related to higher education (HE) in Morocco. An ereadiness survey based on Harvard e-readiness assessment framework is administered in order to check the role of university in getting Morocco e-ready. First, a diagnosis is done at the level of preparedness of Moroccan institutions in networked areas of access, society, economy and policy. The data was collected from the annual reports of Moroccan Telecommunications regulations agency (ANRT), reports from the International Telecommunication Union (ITU), Global Information Technology Report (NRI), quantitative and qualitative surveys from previous research studies, and statistical websites. The findings reveal that Morocco has, apart from networked economy and local digital content, a fairly advanced e-readiness status in other indicators in the model of Harvard Centre of International Development. Ironically, such findings show that it is the Moroccan university that needs to catch up with society.
\end{abstract}

Keywords: ICT, e-readiness, assessment, Networked World, Morocco

\section{Article history:}

Received: 15 November 2019;

Reviewed: 4 December 2019;

Revised: 6 December 2019;

Accepted: 7 December 2019;

Published: 30 December 2019

\author{
Contributor roles: \\ Conceptualization: A.B. (lead); Investigation: A.B., R.E. (equal); \\ Methodology: R.E. (lead); Data curation: R.E. (lead); \\ Formal Analysis: A.B., R.E. (equal); Validation: A.B (lead); \\ Visualization: R.E. (lead); Supervision: A.B. (lead); \\ Writing original draft: R.E. (lead); Writing - review and \\ editing: A.B. (lead); Project Administration: R.E. (lead);
}

Copyright (C) 2019 Abdelmajid Bouziane and Rachid Elaasri

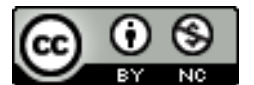

This open access article is published and distributed under a CC BY-NC 4.0 International License which permits non-commercial use, distribution, and reproduction in any medium, provided the original author and source are credited. Permissions beyond the scope of this license may be available at a.bouziane@flbenmsik.m. If you want to use the work commercially, you must first get the author's permission.

Citation: Bouziane, A., \& Elaasri, R. (2019). Morocco E-Readiness Assessment: University Contribution. English Studies at NBU, 5(2), 203-219 https://doi.org/10.33919/esnbu.19.2.2

\begin{abstract}
Abdelmajid Bouziane is a professor of education at Hassan II University of Casablanca, Morocco. He has served as a project manager and participant in different national and international projects related to education. He has published widely in the areas of teaching English as a foreign language, ICT, and education in general. He serves as a peer reviewer for some international journals. His areas of interest are: TEFL, ICT in education, research methods, teachers' associations, and language policy. He has supervised several master and doctorate theses.
\end{abstract}

E-mail: a.bouziane@flbenmsik.ma

https://orcid.org/0000-0002-4138-2450

Rachid Elaasri is a teacher of English at the Preparatory Classes for Engineering Schools and coordinator of its language department office. He is also a doctoral candidate at the University of Hassan II where he conducts his research on ICT implementation in higher education in Morocco.

E-mail: rachidelaasri@gmail.com

https://orcid.org/0000-0001-6456-9237 
Despite the continuous efforts, developmental initiatives, high investments, and previous research implications, the use of ICT in higher education in Morocco can be best described as sporadic, or in some cases as lagging behind. From a critical perspective, there is ample evidence to denote that there is a missing link between the official objectives of ICT use and day-to-day practices. While this is often attributed to internal factors (from within the university), this study considers, at a first stage, the wider "macro" level (from outside the walls of the university) on the basis of actual data of the advancement of Moroccan community in most critical ICT usage fields. It is assumed that the current stage of Morocco's e-readiness may have some potential impact on the implementation of ICT in the Moroccan university. To check this assumption, the first step is to conduct an e-readiness assessment which enables multistakeholders and policymakers to have more visibility as to the current state of preparedness to integrate into the global information society. Findings emanating from the analysis in this study will help with the shaping of decision making in advanced ICT implementation in Moroccan university.

It should be acknowledged that some surveys partly addressed readiness issues in Morocco. For example, a detailed report by the world bank (Constant, 2011) provides data to the Infodev newsletter on broadband and internet access in Morocco. It identifies major challenges of broadband infrastructure shortcomings, affordability constraints, and inadequacy of connectivity coverage. Other reports from the ANRT annually disseminate information on the tremendous improvements of the national telecom sector. International business analysists either in Europe or the U.S. have analyzed the trends, practices and expectations of internet access and information infrastructure in the Kingdom (Constant, 2011; Group, 2015b; Hathaway \& Spidalieri, 2018; Kettani \& Moulin, 2014; Schwab, 2014; Zaied, Khairalla, \& Al-Rashed, 2007). Nationally, a large-scale survey of different training providers in Morocco shows that the face-to-face training still dominates (72\%) and e-learning touches only a few transversal domains of training in a blended format (18\%) (Proactech, 2012). Yet, none of these studies or reports have provided detailed data on the level of ICT readiness of Morocco. The present study gathers data from national and international reports, studies, surveys and statistical websites in order to give a closer picture on the state-ofthe art of ICT use in Morocco. It aims to show whether the scarce use of ICT in Moroccan 
universities (Ait Kaikai, 2014, 2015; Bouziane, Ait Kaikai, \& Lamtara, 2018) can be attributed to the e-readiness of society at large. To do so, it intends to answer the following research questions:

1. What is the level of e-readiness in Moroccan society?

2. What is the responsibility of Moroccan university for boosting, or slowing down thereof, e-readiness in Morocco?

\section{Theoretical Background}

"The electronic Readiness" or e-readiness is a given degree of advancement in IT domains through which a community reaches readiness to integrate into global knowledge societies. A definition adopted for this study reads:

"An 'e-ready' society is one that has the necessary physical infrastructure (high bandwidth, reliability, and affordable prices); integrated current ICTs throughout businesses (e-commerce, local ICT sector), communities (local content, many organisations online, ICTs used in everyday life, ICTs taught in schools), and the government (e-government); strong telecommunications competition; independent regulation with a commitment to universal access; and no limits on trade or foreign investment" (CID, 2002, quoted in Bui, Sankaran, \& Sebastian, 2003, p. 6).

By participating in the global information network, developing nations not only help to build a better society but also benefit from the opportunities of using the network to connect and make business with other users (Harvard University, 2000). It is gauged through diagnoses of progress in the fields of ICT use and the quality of its applications. Such assessment provides ample descriptions of e-readiness of communities and implications for strategic planning "Regardless of a country's level of development, readiness is assessed by determining the relative standing of its society and its economy in the areas that are most critical for its participation to the networked world." (Tolica, Sevrani, \& Gorica, 2015, p. 8). E-readiness assessment tools serve communities' policy-makers to measure key indicators, plan for ICT incorporation, and identify critical areas where further effort is required. However, Krull (2003) warns against the inadequacy of assessment alone and puts forward two challenges for 
decision-makers to overcome: "First, they need to understand how ICT can help their countries achieve economic and social benefits, and to set realistic goals accordingly. Second, they must take concrete steps toward effective and sustainable ICT use that will help their countries realize development goals" (Krull, 2003, p. 11). Equally, for an effective use of new technologies, as the world bank claims "a country must be "e-ready" in terms of infrastructure, the accessibility of ICT to the population at large, and the effect of the legal and regulatory framework on ICT use. "If the digital divide is to be narrowed, all of these issues must be addressed in a coherent, achievable strategy that is tailored to meet the local needs of particular countries" (Tan, 2008, p. 139)

In broad terms, the assessment tools can be basically categorized into two dimensions: those that are developed to assess e-business related issues and those targeting e-society concerns. Methodologically, the e-business assessments tools seem to put much focus on physical access to ICT (infrastructure, network and equipment), use of ICT in business as well as macroeconomic environment affecting ICT usage. On the contrary, the e-society assessment tools look at the country's global preparedness to reap the benefits of ICT. Basic areas of their diagnostic evaluations mainly have to do with socio-cultural factors that affect ICT use, integration of ICT into peoples' lives, ICT capacity and training as well as affordability of ICT in the local context. Choosing to use one of the two types of assessment tools depends on the users 'objectives. A model by Shareef, Ojo, \& Janowski, (2008) focuses on goals that mainly address business and ecommerce, the areas in which ICT is used effectively, the political, economic and social factors that affect its growth, and how it can affect people's lives. Another model labelled STOPE (standing for Strategy, Technology, Organisation, People and Environment) with different factors and explanations for each of its constituents is put forward by (Al-Osaimi, Alheraish, \& Bakry, 2006). However, this study uses a modified e-readiness assessment framework developed by the Center of International Development at Harvard (CID), and the adjusted framework contains a set of 14 indicators categorized under four areas of connectivity: network access, networked society, networked economy and network policy. Each of the 14 main indicators is measured through the assessment of sub-categories that comprise 46 sub-indicators in total (see Appendix): 
Table 1

Main indicators of e-readiness

Main Indicators

\begin{tabular}{|c|c|c|}
\hline \multirow{14}{*}{ 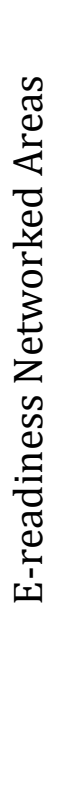 } & \multirow{4}{*}{ Network Access } & Information infrastructure, \\
\hline & & Internet availability, \\
\hline & & Internet affordability, \\
\hline & & Network speed and quality, \\
\hline & \multirow{4}{*}{ Networked Society } & People and organizations online, \\
\hline & & Locally Relevant Content, \\
\hline & & ICTs in Everyday Life, \\
\hline & & ICTs in the Workplace, \\
\hline & \multirow{4}{*}{ Networked Economy } & ICT employment policies, \\
\hline & & $\mathrm{B} 2 \mathrm{~B}$, \\
\hline & & $\mathrm{B} 2 \mathrm{C}$ \\
\hline & & e-government \\
\hline & \multirow{2}{*}{ Network Policy } & Telecommunications regulations \\
\hline & & Trade policy. \\
\hline
\end{tabular}

The CID framework will yield significant information on the degree of readiness of key areas, spot the constraints impeding the effective use of ICT and suggest constructive recommendations. This framework, in addition to external factors, provides measuring tools to assess the internal environment of the organization. The modified version of the CID framework looks comprehensive as it assesses both micro and macro levels. One more interesting point about this framework is that it provides important accounts about education. It includes a major indicator on (networked learning) devoted to assessing key areas in education, namely schools access to ICTs, enhancing education with ICTs, and developing the ICT workforce. It also encompasses indicators of staff training and local digital content. Therefore, the CID covers almost all the factors that influence e-readiness categories such as access to education, government, economy and policy \& regulations. It clearly describes how the tool should be used as well as how to use the results, including identifying potential challenges and key areas with low level of e-readiness. This model is adopted in this study as it seems to be the most suitable to assess the university e-readiness in Morocco. It considers both society- and school-related indicators. Yet, this study does not deal with scores of the networked learning as it focuses more on macro levels of readiness. It mainly considers external factors that may have potential impediments to effective integration of ICT in education and mainly in university. Micro factors like those of university ICT 
infrastructure, professional training, digital content and technical support are handled in a later work and therefore they are beyond the scope of this study.

\section{Methodology}

The staging of each of the four categories was estimated as an average value of the calculated main indicators. The results of the 46 sub-indicators were used to estimate the current stage of each key indicator. These indicators are ranked in a 1 to 4 scale, where 1 represents a lower level and 4 a higher level of ICT preparedness. Numeric values are assigned to each stage. Stage 1 ranges between 0.5 and 1 , stage 2 between 1.5 and 2, stage 3 between 2.5 and 3, and the top stage, stage 4, between 3.5 and 4 . These values are estimated on the availability basis of each sub-indicator; that is, the assigned figure to each sub-indicator is based on the following qualitative perspective: stage 1 means "not available", stage 2 "less available", stage 3 "available", and stage 4 "available enough". It is worth mentioning that "available" stands for an "eready status" while "not available" signifies "not e-ready yet". Calculating the total score of Morocco readiness, however, is not the main purpose of the present study. Rather, it aims to bring the ICT policy planning process to the surface and stimulate a constructive discussion over the ICT critical issues in the country with a particular focus on what hinders ICT implementation in university system.

The data used as the bases of calculations is collected from the annual reports of Moroccan Telecommunications Regulations Agency (ANRT), reports of the International Telecommunication Union (ITU), Global Information Technology Report (NRI), quantitative and qualitative surveys from research studies, and statistical websites.

The compiled data is categorical in nature; the calculations of different factors and sub factors to be considered in the study are calculated and transformed into visual graphs using Microsoft Excel software. The analysis serves to draw some conclusions and implications.

\section{Results}

The main purpose of this study is to find out how widely ICT is integrated in Moroccan society in general. To do so, an overview of existing reports helps to figure out the e-readiness status of Morocco's ICT usage as related to four areas of use: network access, networked society, networked economy, and network policy. The study 
uses a modified e-readiness assessment framework developed by the Center of International Development at Harvard for developing communities. The results of the study are presented below (see Appendix 1 for detailed calculations of sub-indicators):

Table 2

E-readiness Indicators Rankings

\begin{aligned} & \hline Indicator CID ranking \\ & \hline NETWORK ACCESS 2.676 \\ & NETWORKED SOCIETY 2.152 \\ & NETWORKED ECONOMY 1.082 \\ & NETWORK POLICY 3.25 \\ & \hline\end{aligned}

The collected data reveals low to high preparedness levels of e-readiness. It is clear from the figures in Table 1 that apart from networked economy, Morocco has a fairly high e-readiness status in all of the indicators provided by the Harvard Center of International Development. Table 2 shows that the network policy has scored the highest readiness level of the four indicators with a 3.25 score. The second best score has been granted to the network access. With little difference, the networked society reached an above average score. The indicator that achieved the lowest degree of digital preparedness and that seems to need more performance is networked economy.

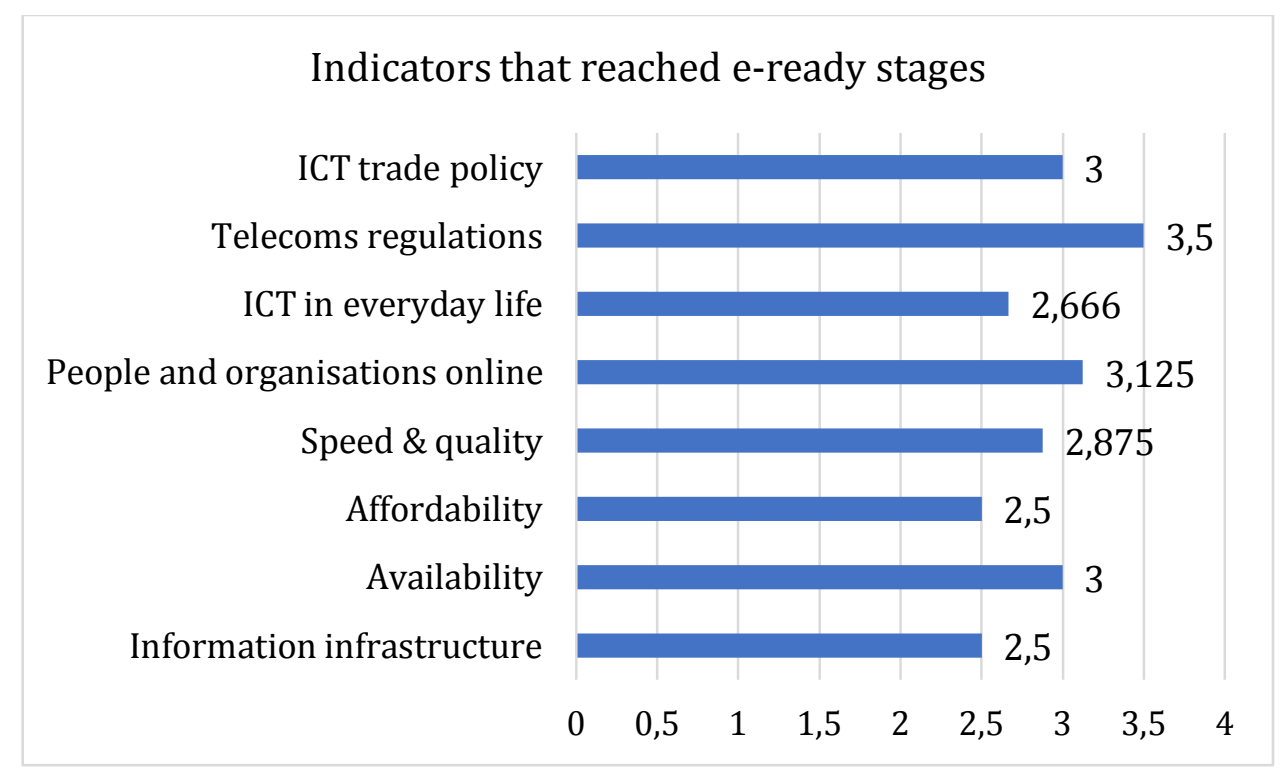

Figure 1. The indicators showing above average to high rankings on the CID

Figure 1 shows the indicators that achieved levels enabling them to gain the status of e-readiness. The section of network policy, which includes telecommunication 
regulations and trade policy reached advanced stages of electronic preparedness ranging between stage 3 and 4 where noticeable progress is being made in telecoms services and businesses, namely the presence of independent regulatory body, foreign direct investments, liberalized trade market, and vibrant competition among mobile wireless providers. The two subcategories of the networked society indicator, ICT in everyday life and people \& organizations online, also reached high e-readiness positions where readiness depends upon the community's incorporation of ICTs into the fabric of its daily activities. Similarly, the network access, including information infrastructure, affordability, availability, and speed and quality, achieved levels beyond average ranking.

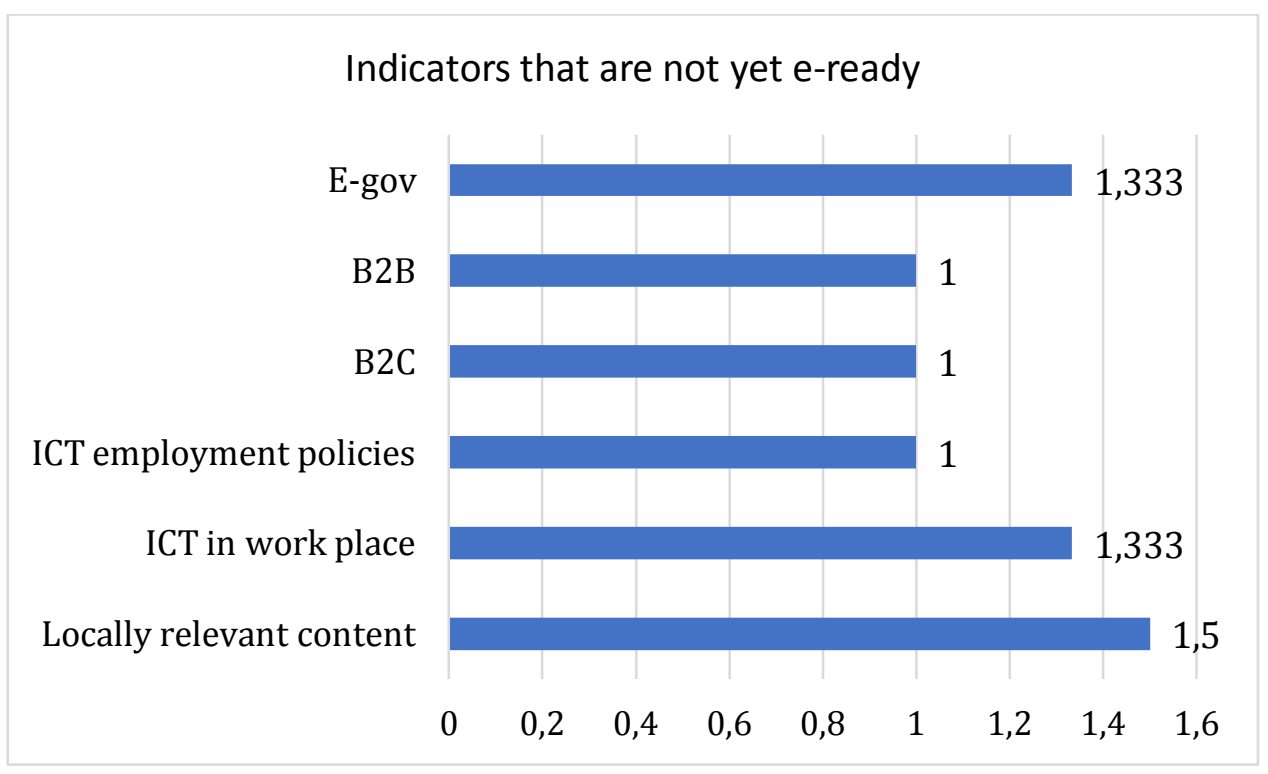

Figure 2. The indicators showing low rankings on the CID

Figure 2 shows the indicators that need boosting according to the existing data and reports. These sub-indicators failed to reach the minimum conditions to gain the benefits of the networked world. The top indicator, locally generated digital content, which is a major driver of growth of IT usage has reached only 1.5 while the other indicators have scored lower ranging from 1 to 1.3 .

The findings in this part answer the research questions. They show that generally Morocco is e-ready in three out of the four assessed areas. The areas that are developed have very little to do with training in universities or colleges. However, those that need improvements are those to which the universities are expected to contribute. Failing to prepare potential people to generate locally relevant content, to use ICT in workplace, to launch $\mathrm{B} 2 \mathrm{~B}$ or $\mathrm{B} 2 \mathrm{C}$ or e-gov online practices, to fit in the ICT employment 
policies can be related to university failure. Preparing people for these tasks will boost the use of ICT in Moroccan universities (see Chan, 2016) on the economic and social benefits for completing a college degree). Concretely speaking, the obstacles of using ICT in Morocco, both at work and in studies, are not related to infrastructure or hardware or software; rather, they are related to human resources.

\section{Discussion}

Looking into the e-readiness of higher education institutions requires revisiting their role in society and reviewing their internal indicators. Cautiously, the three main indicators that scored above the average of e-readiness need further scrutiny as some of the sub-indicators still need further improvements to meet the requirements (see Appendix 1) as discussed in the subsequent part.

The sub-indicators that failed to gain advanced stages of readiness in the Networked Society are those related to generating local content. Some content is generated by citizens at all levels of the country. Many websites provide dynamic information on local topics and are often updated and a significant amount of information is available through websites in local languages especially in social media websites. However, a shortage of local community and business digital content in Morocco is salient. A good number of national websites are neither hosted locally nor updated regularly. For example, more than 90\% of internet traffic involves web resources located outside the Kingdom (Kettani, 2015). Moreover, most of the existing digital content is largely basic information mostly generated by social media users, email exchanges or news web pages. Within the four strategic priorities of MarocNumeric 2013 ("Portal MEF | Ministry of Economy and Finances," 2013) was the development of local content capable of raising the interest of Moroccan users to consume, produce and promote the Moroccan digital content. Unlike what has been planned for and achieved by the government with the e-maroc strategy so far, social content has progressed significantly in comparison with e-government and economic contents. ANRT in 2015, for example, reported that social networks, media and news, sports and gaming and leisure represent the favourite content for Moroccan internet users (ANRT, 2015). In another report published by the Nielson magazine in 2014 (Nielsen, 2014), it is stated that social networks top the list of activities with $77 \%$ of internet subscribers. Streaming online videos is a number one habit of Moroccan 
internet users as 42 percent of these users spend time watching video. Chats (38\%), downloads (29\%) and emails (19\%) are also included in the list of the Moroccans' favorite online activities. The same findings are confirmed by Oukarfi (2013) in a paper investigating 1030 respondents which assesses "the second digital divide" show that Moroccans mainly use the internet for mailing (79\%) and social networks (78\%) and information seeking (77\%). In contrast, there is an alarming lack of e-government and economy contents, though, according to (Kettani, 2015), big budgets have been invested in e-Morocco programs. Action is needed to fix several failures related to rather poor egovernment applications, shortage of local data and limited social impact.

Another sub-part of the above main indicator, ICTs in the Workplace, also lags behind. For an organization to rank at the fourth stage it must achieve major efficiency gains through the deployment of IT systems, in-house computers are supposed to be fully networked nationally or internationally and most employees have internet access from their own workstations. According to the Oxford Business Group (OBG) report of 2015, Morocco still must invest more efforts, energy and time to meet the desired objectives of its new technologies projects with particular focus on the business sector. While the World Economic Forum, in its “Global Competitiveness Report (2014)" ranked the kingdom $57^{\text {th }}$ out of 144 countries in terms of the availability of the latest technologies, it scored poorly in terms of firm-level technology absorption and was ranked in the $75^{\text {th }}$ position (Group, 2015a). The OBG reports that despite private sector dynamics and government-led policies, a large share of small and medium-sized enterprises (SMEs) in the country still lack adequate insertion of new technologies into their daily operations and transactions.

It is quite surprising that none of the four sub-indicators (ICT employment opportunities, B2B, B2C, and e-government) of the Networked Economy overpasses stage one. This category deals with businesses and governments that employ ICT to find more sophisticated ways of managing their external relationships and communications. Accordingly, several auxiliary measures were also planned along with Digital Morocco strategy to set up a specialized committee with the goal to manage the human capital, customize training packages in order to fit the needs of the IT industry and, revise engineering schools, (The Moroccan Government, 2013). A sector that stands, according to Bouzoubaa, a general manager at Sigmatel, an IT services firm, as a major challenge in 
Morocco. Bouzoubaa reported to the OBG that "IT academic programs in universities and engineering schools are mainly focused on technical skills and not enough on management and soft skills. The graduates are not well prepared for professional life: they don't know much about how a company operates," (Group, 2015b, p. 262). In terms of hiring qualified IT profiles, the OBG confirms the difficulty of finding staff with IT competencies and language skills; they either lack one or the other. Morocco's rank according to the global competitiveness index in terms of skills is 114 out 140 countries and 117 in terms skill set graduates (Schwab, 2017).

The country's economic growth and foreign business investments had positive impact on IT sector in the last ten years. This is witnessed in the continuous progress of the telecoms industry as well as in the consolidation of a promising outsourcing sector, which has been attracting international and local investment. Yet, as a common practice in the current business context, Morocco's IT sector remains unbalanced as only a very small portion (10\%) of companies monopolizes the biggest share $(80 \%)$ of the sales market, knowing that most IT investors consist of smaller domestic operators (Group, 2015a). With less qualified staff, market monopoly, international competitors and fragmented IT sector, online trading will not worth serious investments.

The figures provided by international trade specialists and economists on export.gov webpage shows that most of business to business (B2B) transactions in Morocco are done offline. Quite inexplicable, the country has one of Africa's highest internet penetration rates and e-commerce is being built on such infrastructure, there is still a lack of online payment systems which will enable both businessmen and customers to make purchases of large volume.

E-government, as defined by the central government, is making available online administrative services in order to enrich the digital content and make the administration interacting with the public in better ways, speedy manner, and with higher productivity (The Moroccan Government, 2013). Within this framework, some administrative projects were initiated; namely, Service-Public.ma, public portal which aims to promote administrative procedures and e-government services available online; the interoperability centre that aims to publish the national ICT standards/protocols; to share government platforms, applications and services; and to encourage the use of open/free software (Gouvernement du Maroc, 2011). These initiatives were costly on 
the national budget but achieved few outcomes as proved by Kettani (2015) who claims that the outcomes of e-services are too low or even non-existent. According to Kettani, there are few transactional portals; the national interoperability platform of eGovernment has simply not been developed; many projects are simply not implemented, including e-Health, e-Wilaya, e-Invest, Cyberbases, CACs, e-procurement, e-Tenders, DGCL while other projects are weakly implemented such as e-Justice, GENIE, Regional Portals, eFoncier, Damancom, etc. The fact that none of the sub-indicators achieved an average stage can be attributed either to the inappropriateness of the "Rupture" and "Counter Reaction" management style in building up efficient ICT strategies or lack of transparency, limited citizen contributions, entrenched bureaucracy, corruption, regressive policy and unskilled human resources (Kettani, 2015; Schwab, 2014, 2017).

Ironically, all the missing sub-indicators are more related to capacity building of human resources. This is the university system's business par excellence. Therefore, if universities launch courses that address the missing sub-indicators that are far below the average, they will already get into the trend of serving the job market and responding to society's needs. Training college students on e-commerce, e-governance, IT skills, digital content creation and data management will not only help these students start a career, but it will scale up the countries status among the information societies as well.

\section{Conclusion and recommendations}

The purpose of this study is to measure the e-readiness status of Moroccan ICT usage in terms of four areas of use: network access, networked society, networked economy, and network policy. Particularly, it aims to check the role of university in boosting the use of ICT by society. The study used a modified e-readiness assessment framework developed by the Center of International Development at Harvard for developing communities. While three of the four indicators target achieve above average to high ranks of e-readiness, one main indicator, networked economy and two subindicators, local digital content \& ICT in workplace, fail to reach at least average stages. Morocco is gradually aspiring to integrate the networked societies in the world and thus join the information society. However, more care and attention are expected to be devoted to developing digital contents in areas of education, administration and economy. 
Although the overview of existing reports suggests that Morocco is to a greater extent satisfactorily e-ready, it identifies some major challenges that can impede future initiatives for gaining respectable position within the information societies. These challenges include poor e-government and economy contents, inadequate insertion of ICTs in the workplace, limited IT access in business, and inefficient or inexistent business to business online interactions. Therefore, some recommendations are put forward.

Training is the key measure to overcome the existing deficiencies. A professional training in technology skills should be scheduled to help improve the utilization of business transactions, and businesses are expected to incorporate the World Wide Web into their sales, marketing, and customer service systems. Moroccan websites of national domains are supposed to provide dynamic information on local topics in local language. Citizens at all levels of society should be encouraged to generate digital data through websites, online bulletin-board systems, Usenet groups, newsletters, and/or blogs. The Government needs to address the issue of poor e-gov content and deficient applications. It should endeavour to enrich the digital content and provide quality services to the public. To reach all these suggestions, the Moroccan universities need to design adequate curricula to enable their graduates to get ready as technicians, engineers, digital content writers, bloggers, programmers, designers, developers etc. to meet the requirements for the demanding challenges of information society. By doing so, they will serve both themselves and society.

The present study has some limitations. It surveys secondary data from national and international reports rather than collecting its primary data from a representative sample. As such, a nationally extensive e-readiness assessment launched by multiple specialists is needed. In addition, the use of another e-readiness assessment tool might have revealed that the network indicators may score better.

The main conclusion of this overview is that Morocco has gone through major improvements in terms of regulations, infrastructure and access during the last ten years. There are still some major challenges that require immediate intervention, particularly boosting market dynamism, ICT skill and capacity building, upgrading labor market, and generating local digital content. Building up on the achieved gains in order to overcome the impediments of ICT integration should be handled even more rigorously by different stakeholders. 


\section{References}

Ait Kaikai, H. (2014). Appropriation des Technologies de l'Information et de la Communication au sein de l'Université marocaine: Perceptions des étudiants. 17.

Ait Kaikai, H. (2015). Perceptions et usages des TIC au sein de l'université Marocaine: Cas des universités du centre. Unpublished (Doctoral dissertation, University Hassan II, Casablanca.

Al-Osaimi, K., Alheraish, A., \& Bakry, S. H. (2006). An integrated STOPE framework for ereadiness assessments. 18th National Computer Conference. Saudi Computer Society, 1-10. https://www.researchgate.net/publication/216564067 An Integrated STOPE Fr amework for e-Readiness Assessment

ANRT. (2015). Evaluation de la qualité de service. des réseaux publics de télécommunications au Maroc. Retrieved from https://www.anrt.ma/sites/default/files/2015-Qos-Data-3G-fr.pdf

Bouziane, A., Ait Kaikai, H., \& Lamtara, S. (2018). Facilitateurs et barrières de l'intégration des TICE dans l'enseignement marocain: Regards croisés. 1-17.

Retrieved from https://www.researchgate.net/publication/334762803 Facilitateurs et barrieres de l'integration des TICE dans l'enseignement marocain regards croises

Bui, T. X., Sankaran, S., \& Sebastian, I. M. (2003). A framework for measuring national ereadiness. International Journal of Electronic Business, 1(1). https://doi.org/10.1504/IJEB.2003.002162

Chan, R. Y. (2016). Understanding The Purpose of Higher Education: An Analysis of the Economic and Social Benefits for Completing a College Degree. Journal of Education Policy, Planning and Administration 6(5), 1-40.

Constant, S. M. (2011). Broadband in Morocco: Political will meets socio-economic reality. The International Bank for Reconstruction and Development / The World Bank.

Gouvernement du Maroc. (2011). eGov Maroc: Programme e-Gouvernement du plan Maroc Numeric. Retrieved from http://www.egov.ma/fr

Group, O. B. (2015a). The Report: Gabon 2015. Oxford Business Group.

Group, O. B. (2015b). The Report: Morocco 2015. Retrieved from https://oxfordbusinessgroup.com/morocco-2015

Center of Internation Develompent. (2000). Readiness for the networked world: A guide for developing countries. Center for International Development, Harvard University.

Hathaway, M., \& Spidalieri, F., \& Alsowailm, F. (2018). Kingdom of Saudi Arabia Cyber Readiness at a Glance .Potomac Institute for Policy Studies, September 2017.

Kettani, D. (2015). Assessing ICT Policy Development and Implementation in Developing Countries: A Case Study from Morocco. International Journal of Emerging Trends \& Technology in Computer Science 4(2), 1-6.

Kettani, D., \& Moulin, B. (2014). L'e-gouvernement pour la bonne gouvernance dans les pays en développement. Centre de recherches pour le développement international. 
https://idl-bnc-idrc.dspacedirect.org/bitstream/handle/10625/52695/IDL52695.pdf

Krull, A. (2003). ICT Infrastructure and E-readiness Assessment Report: Estonia. PRAXIS Center for Policy Studies.

Nielsen, company. (2014). Navigating the Moroccan Internet User's Online Habits. Retrieved from http://www.nielsen.com/ma/en/insights/news/2014/navigatingthe-moroccan-internet-users-online-habits

Oukarfi, S. (2013). L'usage de l'Internet au Maroc: Essai de mesure de la fracture numérique de second degré [ The use of the Internet in Morocco: Test for measuring the second digital divide]. International Journal of Innovation and Applied Studies 2(2), 118-130.

Ministry of Economy and Finances. (2013). Investments. Retrieved from https://www.finances.gov.ma/en/Pages/Strat\%C3\%A9gies/Strat\%C3\%A9gieMaroc-Numeric-2013.aspx?m=Investors\&m2=Investments

Proactech. (2012). 1er Baromètre du e-Learning au Maroc. Retrieved from http://www.taalimtice.ma/fr/sites/default/files/1er\%20Barom\%C3\%A8tre\%20 du\%20e-Learning\%20au\%20Maroc\%20-\%20Mars\%202012.pdf

Schwab, K. (2014). The Global Competitiveness Report. Retrieved from http://www3.weforum.org/docs/WEF GlobalCompetitivenessReport 2014$\underline{15 . p d f}$

Schwab, K. (2017). The Global Competitiveness Report 2017-2018. World Economic Forum. Retrieved from http://www3.weforum.org/docs/GCR20172018/05FullReport/TheGlobalCompetitivenessReport2017\%E2\%80\%932018.pd $\underline{\mathrm{f}}$

Shareef, M., Ojo, A., \& Janowski, T. (2008). A readiness assessment framework for egovernment planning: Design and application. In: Proceedings of the $2 \mathrm{nd}$ international conference on Theory and practice of electronic governance (ICEGOV '08), Association for Computing Machinery, New York, 403-410. https://doi.org/10.1145/1509096.1509180

Tan, Y. (2008). Creative urban regions: harnessing urban technologies to support knowledge city initiatives. Information Science Reference Publishing (IGI Global): Hershey.

The Moroccan Government. (2013). Allintitle: "Stratégie Nationale pour la Société de l'Information et de l'Économie Numérique","Recherche Google. Retrieved from http://www.egov.ma

Tolica, E. K., Sevrani, K., \& Gorica, K. (2015). Information Society Development through ICT Market Strategies: Albania versus Other Developing Countries. Springer. https://doi.org/10.1007/978-3-319-17196-8

Zaied, A. N. H., Khairalla, F. A., \& Al-Rashed, W. (2007). Assessing e-Readiness in the Arab Countries: Perceptions Towards ICT Environment in Public Organisations in the State of Kuwait. The Electronic Journal of e-Government 5(11), 77-86. 
Appendix 1: Details of e-readiness calculations

\begin{tabular}{|c|c|c|c|c|c|c|}
\hline $\begin{array}{l}\text { Network } \\
\text { area }\end{array}$ & $\begin{array}{c}\text { Main } \\
\text { indicators }\end{array}$ & Sub indicators & Stage & Average & Mean & $\begin{array}{l}\text { Readiness } \\
\text { status }\end{array}$ \\
\hline \multirow{20}{*}{ 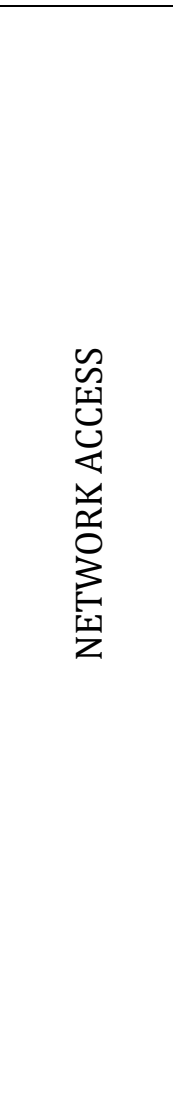 } & \multirow{4}{*}{$\begin{array}{l}\text { Information } \\
\text { Infrastructure }\end{array}$} & Teledensity & 1.5 & \multirow[b]{4}{*}{ Average } & \multirow{20}{*}{2.676} & \multirow{20}{*}{ e-ready } \\
\hline & & wireless penetration & 4 & & & \\
\hline & & $\begin{array}{r}\text { Cable service } \\
\text { subscribers } \\
\end{array}$ & 2 & & & \\
\hline & & & 2.5 & & & \\
\hline & \multirow{7}{*}{ Availability } & ISPs per $1,000,000$ & 3.5 & & & \\
\hline & & bandwidth solutions & 3.5 & & & \\
\hline & & web hosting services & 3.5 & & & \\
\hline & & public Internet access & 3.5 & & & \\
\hline & & dial-up connection & 3 & & & \\
\hline & & $\begin{array}{r}\text { Private leased lines to } \\
\text { businesses }\end{array}$ & 1 & & & \\
\hline & & & 3 & Average & & \\
\hline & \multirow{4}{*}{ Affordability } & Cost for internet & 1.5 & & & \\
\hline & & Prices competition & 2.5 & & & \\
\hline & & Prices decrease & 3 & & & \\
\hline & & & 2.33 & Average & & \\
\hline & \multirow{5}{*}{$\begin{array}{l}\text { Speed \& } \\
\text { Quality }\end{array}$} & Dropped connections & 3.5 & & & \\
\hline & & domestic calls success & 2.5 & & & \\
\hline & & Mainlines faults & 2 & & & \\
\hline & & High speed & 3.5 & & & \\
\hline & & & 2.87 & Average & & \\
\hline
\end{tabular}

\begin{tabular}{|c|c|c|c|c|c|c|}
\hline $\begin{array}{l}\text { Network } \\
\text { area }\end{array}$ & $\begin{array}{c}\text { Main } \\
\text { indicator }\end{array}$ & Sub indicator & Stage & Average & Mean & $\begin{array}{l}\text { Readiness } \\
\text { status }\end{array}$ \\
\hline \multirow{17}{*}{ 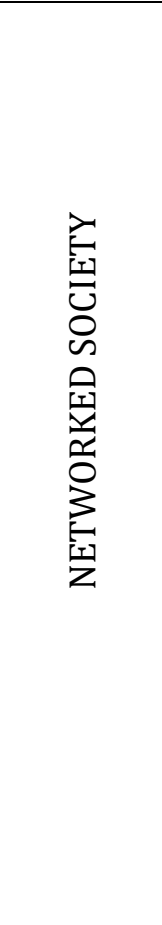 } & \multirow{5}{*}{$\begin{array}{c}\text { People \& } \\
\text { organizations } \\
\text { online }\end{array}$} & Internet users & 3.5 & \multirow[b]{5}{*}{ Average } & \multirow{17}{*}{2.152} & \multirow{17}{*}{ e-ready } \\
\hline & & Regular internet access & 4 & & & \\
\hline & & $\begin{array}{r}\text { Locally registered } \\
\text { domains }\end{array}$ & 4 & & & \\
\hline & & Online advertising & 1 & & & \\
\hline & & & 3.12 & & & \\
\hline & \multirow{4}{*}{$\begin{array}{l}\text { Locally } \\
\text { Relevant } \\
\text { content }\end{array}$} & Online local content & 1.5 & \multirow[b]{4}{*}{ Average } & & \\
\hline & & Content creators & 1 & & & \\
\hline & & Local websites content & 2 & & & \\
\hline & & & 1.5 & & & \\
\hline & \multirow{4}{*}{$\begin{array}{c}\text { ICT in } \\
\text { everyday life }\end{array}$} & Personal use of ICT & 3 & & & \\
\hline & & ICT social use & 2 & & & \\
\hline & & Public internet access & 3 & & & \\
\hline & & & 2.66 & Average & & \\
\hline & \multirow{4}{*}{$\begin{array}{l}\text { ICT in work } \\
\text { place }\end{array}$} & Networked computers & 2 & \multirow[b]{4}{*}{ Average } & & \\
\hline & & Internet at work & 1 & & & \\
\hline & & Professional emails & 1 & & & \\
\hline & & & 1.33 & & & \\
\hline
\end{tabular}




\begin{tabular}{|c|c|c|c|c|c|c|}
\hline $\begin{array}{l}\text { Network } \\
\text { area }\end{array}$ & $\begin{array}{c}\text { Main } \\
\text { indicator }\end{array}$ & Sub indicator & Stage & Average & Mean & $\begin{array}{l}\text { Readiness } \\
\text { status }\end{array}$ \\
\hline \multirow{15}{*}{ 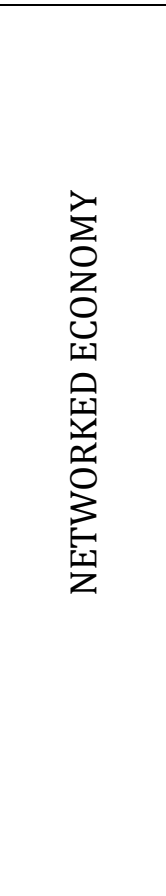 } & \multirow{4}{*}{$\begin{array}{c}\text { ICT } \\
\text { employment } \\
\text { policies }\end{array}$} & Technical skills & 1 & \multirow[b]{4}{*}{ Average } & \multirow{15}{*}{1.082} & \multirow{15}{*}{$\begin{array}{l}\text { Not e- } \\
\text { ready }\end{array}$} \\
\hline & & Trade management & 1 & & & \\
\hline & & ICT trade strategy & 1 & & & \\
\hline & & & 1 & & & \\
\hline & \multirow{3}{*}{ B2C } & Business online & 1 & & & \\
\hline & & Online retail & 1 & & & \\
\hline & & & 1 & Average & & \\
\hline & \multirow{4}{*}{$\mathrm{B} 2 \mathrm{~B}$} & B2B online transactions & 1 & \multirow[b]{4}{*}{ Average } & & \\
\hline & & B2B online sales & 1 & & & \\
\hline & & Business online tracking & 1 & & & \\
\hline & & & 1 & & & \\
\hline & \multirow{4}{*}{ E-gov } & $\begin{array}{r}\text { Public agency online } \\
\text { content }\end{array}$ & 2 & \multirow[b]{4}{*}{ Average } & & \\
\hline & & $\begin{array}{r}\text { Interactive government } \\
\text { webs }\end{array}$ & 1 & & & \\
\hline & & $\begin{array}{r}\text { Government online } \\
\text { mediation }\end{array}$ & 1 & & & \\
\hline & & & 1.33 & & & \\
\hline
\end{tabular}

\begin{tabular}{|c|c|c|c|c|c|c|}
\hline $\begin{array}{c}\text { Network } \\
\text { area }\end{array}$ & $\begin{array}{c}\text { Main } \\
\text { indicator }\end{array}$ & Sub indicator & Stage & Average & Mean & $\begin{array}{c}\text { Readiness } \\
\text { status }\end{array}$ \\
\hline \multirow{8}{*}{ 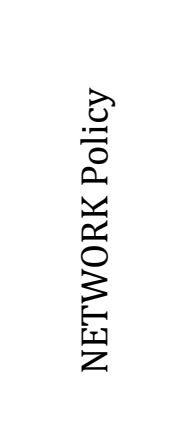 } & \multirow{4}{*}{$\begin{array}{l}\text { Telecoms } \\
\text { regulations }\end{array}$} & Liberalized telecom sectors & 3.5 & & \multirow{8}{*}{3.25} & \multirow{8}{*}{ e-ready } \\
\hline & & Effective regulations & 3 & & & \\
\hline & & $\begin{array}{r}\text { Independent regulatory } \\
\text { body }\end{array}$ & 4 & & & \\
\hline & & & 3.5 & Average & & \\
\hline & \multirow{4}{*}{$\begin{array}{l}\text { ICT trade } \\
\text { policy }\end{array}$} & ICT tariffs & 3 & & & \\
\hline & & Liberalized trade services & 2.5 & & & \\
\hline & & ICT foreign investors & 3.5 & & & \\
\hline & & & 3 & Average & & \\
\hline
\end{tabular}

